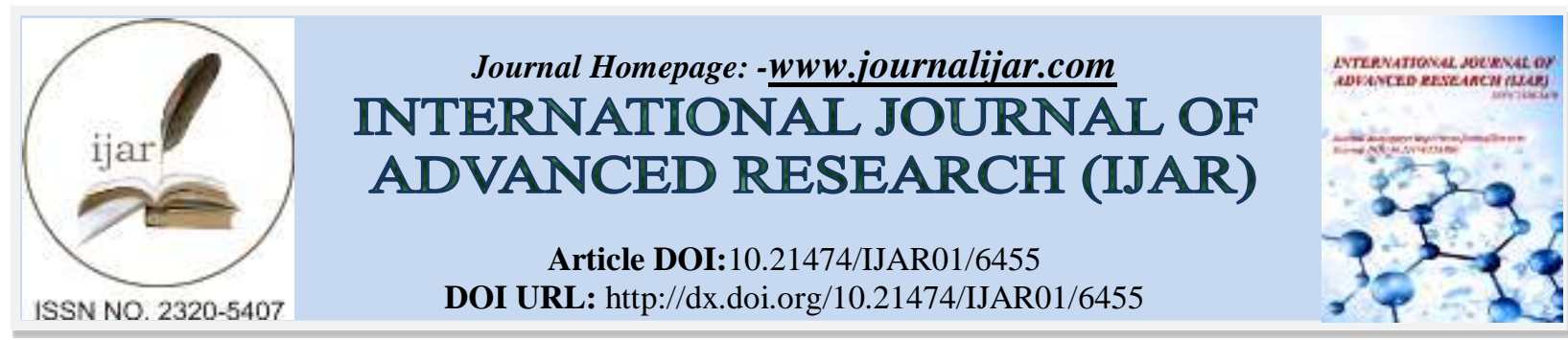

RESEARCH ARTICLE

\title{
INVESTIGATION OF THE BASIC QUALITATIVE PROPERTIES OF THE DASHSALAHLI DEPOSIT OF BENTONITE CLAYS.
}

\begin{abstract}
Afandiyeva Z. J.
Assistant professor, candidate of technical sciences Azerbaijan State University of Oil and Industry, Azerbaijan Republic
\end{abstract}

\section{Manuscript Info}

Manuscript History

Received: 05 December 2017

Final Accepted: 07 January 2018

Published: February 2018

Keywords:-

bentonite clay, cations, dispersity,

properties, swelling, chemical

composition.

\begin{abstract}
The conducted investigations showed that the total capacity of exchangeable cations of Dashsalahli bentonite clays ranges from 55 to $166 \mathrm{mg} / 100 \mathrm{~g}$. The contents of exchangeable sodium cations vary from 22 to $65.2 \mathrm{mg}$. eq / $100 \mathrm{~g}$ in them; on average $43.2 \mathrm{mg}$ eq/100g and granulometric composition of clay in all sites are identical and refer to fine-dispersed.

It was established that, bentonite clays of different areas in Dashsalahli deposit have unequal swelling in water, caused to a great extent by granulometric composition of the original rocks: the larger the finedispersed fraction, the higher the swelling or vice versa. This pattern is observed in all areas of the deposit.

It has been determined that, high swelling has alkaline bentonites in the water environment. These differences of bentonites are able to absorb more than tenfold amount of water, while increasing in volume more than 15-20 times against the original. Water penetrates to the primary particles of bentonite through the capillaries and around them forms water shells that wedge the particles. As a consequence, a strong increase in the total volume of clay occurs.
\end{abstract}

Copy Right, IJAR, 2018,. All rights reserved.

\section{Introduction:-}

The name of bentonite clays was derived from the area of Fort Benton (USA), where initially they were discovered and began to be mined in late 19th century.

In the subsequent interest in bentonite clays was dramatically increased, and their deposits were discovered in many countries around the world.

Bentonites are classified as fine-dispersed clays, $60-70 \%$ of which are the minerals of montmorillonite group and possess high coupling capacity, adsorption and catalytic activity.

Basic mineral of bentonite clays is montmorillonite, the last name of which was derived from Montmorillon (France), where it was initially discovered. In England, bentonites were termed as "fuller land" (coarse clays used mainly for degreasing the coat)(2005, Eisenhour and Reisch 2006, Krugin and Bunidorova 2011) 
In CIS countries, names of various deposits bentonite are mostly taken by pointing to the location of the object: "gumrin" from the name "Gumbri" of Sakhaltub district in Georgia, "oglangel" from the name "Oglanli" in Turkmenistan, "gilabi" is the name of bentonites in Azerbaijan, which were used by the local population as a bleaching agent(Merabishvili 1979, Afandiyeva 2007).

Application field of bentonite is extremely wide: metallurgical, oil and gas, foundry, petrochemical, oil refining, chemical, light agricultural industry, as well as it is used for improving the soil fertility. Currently, bentonite clays are widely used in the production and enrichment of iron ore and production of iron ore concentrate. In this regard, they are the main raw material on the world market(Afandiyeva 2007, Celik 2010,Chisholm 1960, Karnland 2010,Zamchalin et al., 2015)

Thanks to developing oil industry of Azerbaijan, interest in investigating the geologic structure of bentonite deposits has increased. In terms of bentonite production by annual output $1 \div 1.5$ million tons, the industrial development of the largest field in Dashsalahli deposit is planned for the next $40 \div 50$ years (explored deposits of 180 million tons). In terms of the quality of minerals, Dashsalahli deposit is unique and one of the largest deposit in the world.

As the investigation and efficiency of industrial development of the abovementioned promising deposits and world market demand are taken into account, it is possible to increase extraction and processing of bentonites $1.5 \div 2.0$ times in the republic by obtaining various products of benthic-powder, bentocolla, granulated bentonite and others.

\section{Properties of bentonite clays of Dashsalahli deposit:-}

Bentonite clays of Dashsalahli deposit are characterized by specific properties and features. They have gray, bottle greenish, bluish, yellowish or cream colors and while being dried they become lighter. In natural form, bentonite clays possess high plasticity, besides they have a shell or fragmentation fracture, sometimes they contain relicts of weakly modified parent rocks.Fig.1, Fig.2

Mineralogical composition consists mainly of sodium montmorillonite (60-90\%) and hydro-mica (10-15\%) with a subordinate amount of kaolinite, zeolite, calcite, tridymite, and rarely metagallausitis and gypsum.

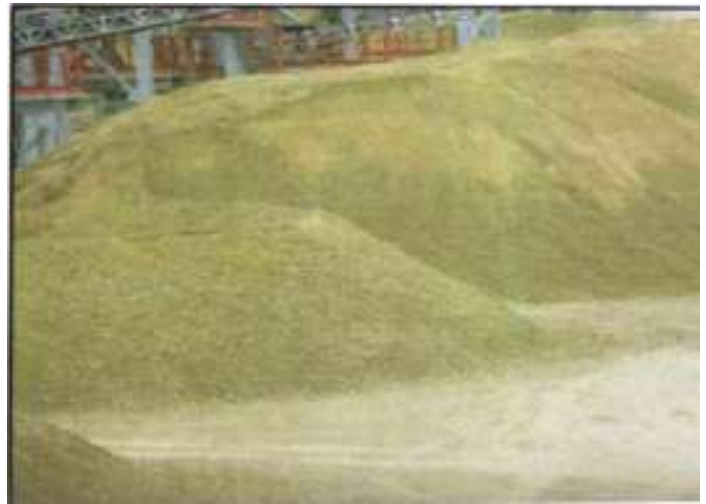

Figure 1:- Green clays Dashsalahli deposit

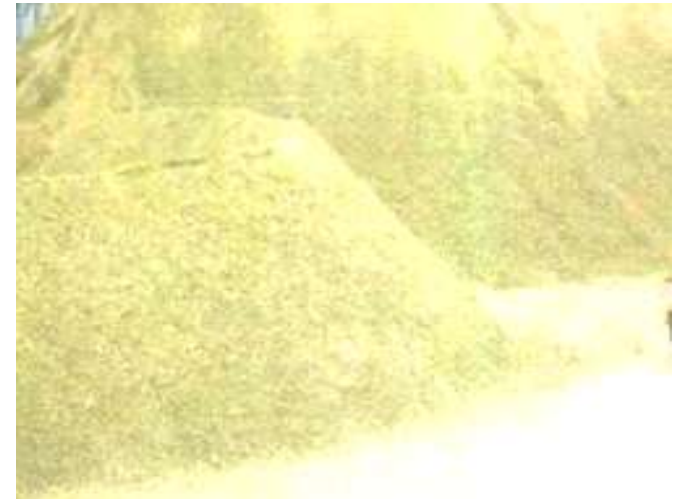

Figure 2:- Yellow clays Dashsalahli deposit

According to the chemical composition, bentonite clays of Dashsalahli deposit belong to aqueous aluminosilicates. The average chemical composition is presented in table 1

Table 1

The average chemical composition of bentonites in Dashsalahli deposit

\begin{tabular}{|l|l|l|l|l|l|l|l|l|l|l|l|l|}
\hline $\begin{array}{l}\text { Composition } \\
\text { of the } \\
\text { components, } \%\end{array}$ & $\mathrm{SiO}_{2}$ & $\mathrm{TiO}_{2}$ & $\mathrm{Al}_{2} \mathrm{O}_{3}$ & $\mathrm{Fe}_{2} \mathrm{O}_{3}$ & $\mathrm{FeO}$ & $\mathrm{MgO}$ & $\mathrm{MnO}$ & $\mathrm{CaO}$ & $\mathrm{Na}_{2} \mathrm{O}$ & $\mathrm{K}_{2} \mathrm{O}$ & $\mathrm{P}_{2} \mathrm{O}_{5}$ & $\mathrm{CO}_{2}$ \\
\hline Yellow clays & 60,03 & 0,85 & 16,69 & 5,86 & 0,21 & 0,09 & 3,69 & 2,65 & 1,94 & 0,53 & 0.18 & 1.32 \\
\hline Green clays & 60,73 & 0,79 & 15,86 & 5,33 & 1,01 & 0,09 & 3,21 & 2,92 & 2,52 & 0,59 & 0.06 & 1.90 \\
\hline
\end{tabular}

Table 1 shows that, chemical composition of bentonite clays is identical. Green bentonite clays differ from the yellow ones with increased content of ferrous oxide $(\mathrm{FeO})$ almost at equal amounts of other components. 
Taking into account the hydrothermal genesis of the deposit, the presence of appreciable quantities of $\mathrm{Mn}, \mathrm{Pb}, \mathrm{Cu}$, $\mathrm{Zn}, \mathrm{Cr}$, Th and other elements adsorbed by clay minerals due to hot waters or preserved relicts from the parent rocks is very typical in the deposit (Dunyamaliev et al., 2004)

Widespread development in bentonites is fludial, perlite, bubbly, pumice-pearlite, rarely detrital, ash relic structures of the parent rocks. Their bentonitization degree significantly depends on technological indicators. The most favorable are pumice and spherulite micro-structures, since their distribution area coincides with development fields of high-quality bentonites.

In montmorillonite $\mathrm{d}_{(001)}=12.4-12.6 \mathrm{~A}$, however, after saturation, glycerol is displaced up to 17.6 - $17.8 \mathrm{~A}(1$ angstrom $\left.\mathrm{A}=10^{-7} \mathrm{~mm}\right)$. Heating the sample to $330^{\circ} \mathrm{C}$ leads to a reduction of $\mathrm{d}_{(001)}$ to $9.5-9.6 \mathrm{~A}$, however, subsequent saturation with glycerin shows that this dehydration is reversible. Irreversible removal of interlayer water occurs at 500-600 ${ }^{\circ} \mathrm{C}$. Reflex (d) (001) does not exceed $1.49 \mathrm{~A}$, and indicates the dioctahedral structural modification of montmorillonite in the described bentonite clays.

\section{Dispersion:-}

One of the important natural features of bentonites is their dispersion, which functionally depends on the genus and quantity of exchangeable cations of clays: the more bentonite particles of exchangeable cations of alkali metals in the diffuse layer, usually sodium, the higher its dispersion. The amount of exchangeable cations is usually expressed in milligrams - equivalents per $100 \mathrm{~g}$ of dry clay.

The amount of fine particles having dimensions less than 0,001 - 0,0015 $\mathrm{mm}$ and high-quality bentonites reaches $85 \%$, and in some cases even it exceeds this limit. The power of bentonites with a fraction less than 0,001 $0,0015 \mathrm{~mm}$ reaches $160 \mathrm{~m}$. The volume of siltstone fraction $0.01-0.1 \mathrm{~mm}$ is $7.5-15 \%$ in clays. The amount of sand fraction having particle sizes more than $0.1 \mathrm{~mm}$ is $2-5 \%$.

Rather strong bond between water molecules and clay particles ensures the latter remain suspended in the aquatic environment for a long time.

In the diffuse layer of particles of natural bentonites, the exchange cations of both alkaline and alkaline-earth metals are almost always contained in dependence mainly on the conditions of their formation (Mostalygina et al., 2010, Khimich 2007,Stanković et al., 2011).

According to the quantitative ratio of alkaline and alkaline-earth cations in the exchange complex, bentonite clays of Dashsalahli lower horizons belong to the categories of the alkali-sodium compound. Alkaline-earth differences are no longer made up of bentonites, but bentonitized tuffs having very low swelling, and are located at the very top of

the deposit. The alkalinity coefficient $\frac{\mathrm{K}^{+}+\mathrm{Na}^{+}}{\mathrm{Ca}^{+}+\mathrm{Mg}^{++}}$ranges from 1.07 to 6, 49, averaging 3.4.

Particles of alkaline-earth bentonites, calcium and magnesium exchange cations are more firmly bound together in the diffuse layer being predominantly less hydrated, dissolve into separate large aggregates in the aqueous medium, which are not able to remain in suspension for a long time and quickly drop out. Such bentonites naturally show low dispersion. The amount of fine-dispersed fractions in alkaline-earth bentonites can be increased artificially. For this, it is necessary to process these bentonites with a small amount of sodium pyrophosphate $\mathrm{NaP}_{2} \mathrm{O}_{7}$ ) or other sodium salts. At the same time, exchange alkaline-earth cations are replaced with sodium cations, as a result bentonite is obtained being completely identical with natural alkaline of fine-dispersed swelling bentonites.

\section{Swelling:-}

Swelling characterizes the capacity of bentonites to absorb water and increase significantly in volume. Finedispersible strongly swelling bentonites with high ironing capacity (60-61), specific surface, and occurrence of the II endo-effect with high temperature $\left(600-700^{\circ} \mathrm{C}\right.$ ) are developed in the Central and Northern sections of Dashsalahli deposit (Afandiyeva 2009). Due to the plasticity value, bentonites (60-164, 1\%) go beyond the I class. These clay differences are suitable in ferrous metallurgy as a binder for the production of pellets of iron ore concentrates and for foundry production. The strength of the molding mixtures is $0.3-0.5 \mathrm{MPa}$ for cast iron and steel casting. 
According to CIMS, preliminary treatment of coarse-dispersed Dashsalahli bentonites with 3\% soda ash, significantly reduces the specific gravity and disaggregates them. After that, they can also be used to produce drilling muds. After processing coarse-dispersed differences (South part) of Dashsalahli bentonites show the properties like adsorption, whitening, catalytic and cracking activity during oil refining, separation of gas-oil fraction of oils, obtaining semi-synthetic catalysts identical with gumbrin (Georgia).

\section{Conclusion:-}

Activation of the above-mentioned clays with $20 \%$ sulfuric acid treatment or saturation of the surface with active cations $\left(\mathrm{H}^{+}, \mathrm{A}^{+} 3\right)$ leads to an increase in the specific surface of adsorption, bleaching, etc., 3 times superior than the gumbrin imported from Georgia. Bleaching of turbine, engine and aviation oils, refining of sunflower, cotton, soybean, margarine oil reaches $80-85 \%$. During purification of wine and juice, Dashsalahli bentonites were the best indicators. They can also be used in the manufacture of medical preparations (antiseptic emulsions, ointments, etc.), soaps, perfume products, and light differences - in the production of writing paper. In agriculture, they are applicable due to capacity of retaining water in soils, water bodies, irrigation canals, and increase crop yields. Bentonites of the Northern part are suitable for the production of fodder carbamide concentrate.

Alkaline earth bentonites slightly swell in water, and some of them practically do not swell. The presence of watersoluble salts, especially alkaline-earth metals, has a negative impact on the swelling of bentonites.

\section{References:-}

1. Afandiyeva Z.J. 2007. Bentonites of Azerbaijan. Journal “Gorniy”. № 4. Moscow: 15-17.

2. Afandiyeva Z. J. 2007. Possible areas for the use of bentonite clays in Azerbaijan. Journal “Gorniy”.№ 10. Moscow: 90-92.

3. Afandiyeva Z.J. 2009. Studying physical and chemical properties of bentonite clays deposits of Azerbaijan and the basic areas of their application. International conference "Clays, clay minerals and layered materials" Moscow: $80-81$.

4. Bentonite, kaolin, and selected clay minerals. 2005. World Health Organization Geneva. 196.

5. Celik H. 2010.Technological characterization and industrial application of two Turkish clays for the ceramic industry, Appl. Clay Sci., 50,245-254.

6. Chisholm, F. 1960. Bentonite in industry: Mines Magazine.30-42.

7. Dunyamaliev F.A., Mukhtarov G.G., Shirinov Y.R. 2004. The main production of bentonite in Azerbaijan. Adiloglu, Baku.377.

8. Eisenhour D, Reisch F. Bentonite. In: Kogel J E (ed). 2006. Industrial minerals and rocks: commodities, markets, and uses. Littleton, Colorado: Society for Mining, Metallurgy, and Exploration. 357-368.

9. Krugin S.V., Bunidorova G.V. 2011. Physical and chemical bases of application of bentonite clays of Bekhterevskoye field for creation of perspective materials of multi-purpose use // Technology of oil and gas. № 6. 32-41.

10. Karnland Ola. 2010. Clay Technology AB Technical. Report TR-10-60. Chemical and mineralogical characterization of the bentonite buffer for the acceptance control procedure in a KBS-3 repository.29.

11. Khimich T.S .2007. Modified additive of bentonite clay for plaster solutions based on Portland cement. Khimich. - Chelyabinsk. 21

12. Merabishvili M.S. 1979. Bentonite clays. Tbilisi. 210.

13. Mostalygina L.V., Elizarova S.N., Kostin A.V.2010.Bentonite clays in solving ecological problems ofthe Zaurals // Problems of regional ecology.№ 1. 158-164.

14. Stanković N., Logar M., Luković J., Radosavljević - Mihajlovic A. 2011. Characterization of bentonite clay from "Greda" deposit Processing and Application of Ceramics.97-101.

15. Zamchalin M.N., Korovkin M.O., Eroshkina N.A. 2015. Investigation of the effect of adding bentonite on the properties of a solution based on composite cement // Young Scientist. № 13. 112-115. 